\title{
Waterfront Development within the Urban Design and Public Space Framework in Malaysia
}

\author{
Ahmed Raad Al-Shams ${ }^{1}$, Kamarudin Ngah ${ }^{2}$, Zaherawati Zakaria ${ }^{3}$, Nazni Noordin ${ }^{3} \&$ Mohd Zool Hilmie \\ Mohamed Sawal ${ }^{4}$ \\ ${ }^{1}$ HBP, Universiti Sains Malaysia (USM), Pulau Pinang, Malaysia \\ ${ }^{2}$ Pusat Penyelidikan Dasar dan Kajian Antarabangsa (CenPRIS), Universiti Sains Malaysia (USM), Pulau \\ Pinang, Malaysia \\ ${ }^{3}$ Faculty of Administrative Science \& Policy Studies, Universiti Teknologi MARA, Merbok, Kedah, Malaysia \\ ${ }^{4}$ Faculty of Information Management, Universiti Teknologi MARA, Merbok, Kedah, Malaysia \\ Correspondence: Zaherawati Zakaria, Faculty of Administrative Science \& Policy Studies, Universiti Teknologi \\ MARA, P. O Box 187, 08400 Merbok, Kedah, Malaysia. Tel: 60-4456-2565. E-mail: \\ zaherawati@kedah.uitm.edu.my
}

Received: March 6, 2013 Accepted: May 21, 2013 Online Published: August 1, 2013

doi:10.5539/ass.v9n10p77 URL: http://dx.doi.org/10.5539/ass.v9n10p77

\begin{abstract}
Historically, waterfronts developments have undergone various stages of development initiatives and become the most challenging tasks for planners and urban designers nowdays. It reflected a dynamic natural resources with special characteristics and regarded as the most important factors that influence the growth and image of the cities and had a significant impact on urbanization and modernization of the most cities in the near future, as experienced by most harbor cities in Europe, North America, Australasia, Japan and others. This paper attempts to understand the evolution of waterfront development within the framework of urban design and public spaces, as been practiced by Singapore and Turkey, and provided lesson to learn by taking Johor Bharu as a case. In future research, the urban studies on waterfronts will be important framework in cities development. The smart-partnership between local government and private should be more emphasized in order to achieve the world-class urban and cities development.
\end{abstract}

Keywords: waterfront development, urban design, public spaces

\section{Introduction}

In 2009, according to the UN report, for the first time in the history more than $50 \%$ of the world population now are living in urban areas (United Nations, 2010), with hope to improve their life and get better future. Therefore, the task of planners, urban designers and architects side by side with politicians became more complicated due to the increasing of urban population, needs of life and size of cities. In addition, cities became not just a place of living and working, but it became also the reflection of people's spiritual and physical culture (Moughtin, 1992). This cultural reflection of people on the physical context of the city can be seen mainly in the stage of urban design, because in this stage, buildings as individual units of the city structure will be connected to each other by roads, nods and open spaces. Thus, moving, gathering and getting a place as daily activities of inhabits affected by their culture from one side and the urban design process from another side.

In the center of the design process is public spaces due to their important role as places of gathering and hosting the cultural and commercial daily activities. For that, recently, a slogan of "Streets for people and not for automobile" (Barnett, 1982) has been raised among planners and urban designers in developing future cities, towards achieving green and sustainable city and increasing the social interaction between people themselves. On the other hand, many of Asian and European cities are located close to a water body. This is relating to the need of using water as a source for drinking, agriculture and then for trade and transport. These water bodies which shaped waterfronts of many cities, recently, emerged as one of the most important issues of urban design and planning disciplines (Butuner, 2006). Because there are not only an edge between urban fabric and water, but due to the variety of roles and functions that waterfront has across the history from a place for trade, transport, industry and nowadays as public open space for recreation and tourism. Therefore, this leads to add a new type 
of public spaces to the city structure and change the image of many cities through offering a different water-city integration model. This article aims to understand the development of waterfront within the framework of urban design and public spaces. In addition, the article discussed the factors that affect this evolution and transformed the waterfront from place for trade, transport and industry to be a place for recreation, tourism and entertainment. Thus, this review and understanding leads to highlight the main points that planners and urban designers should concern in the future development of waterfront in Malaysia and the worldwide.

\section{Literature Review}

Design cities is not a simple process of making pictures showing how the city should look twenty years from now (Barnett, 1982), but it is an attempt to make the future better than the present (Roberts \& Greed, 2001) in terms of social, economic and environmental aspects. Urban design is the result of the integration between architecture and planning, where, the subject matter of urban design is the arrangement of many buildings within a space so that they can form a single composition (Moughtin, 1992). Historically, the urban design concept is based on man, his values, aspirations and power or ability to achieve them (Moughtin, 1992). Therefore, from the antiquity till the early renaissance, urban design usually was the reflection of the current religious beliefs in cosmic harmony to shape the notion of the Ideal City (Akkerman, 2000).

During the renaissance time, a new shifting had been happened influenced the designing of cities, from the classic Ideal Romanian City to the Ideal Industrial City. This shifting was the result of influencing from the image of success in science (Buck-Morss, 1990), as shown in the design of Garden City by Ebenezer Howard (1898) (Figure 1) and La Ville Radieuse by Le Corbusier (1933) (Figure 2).

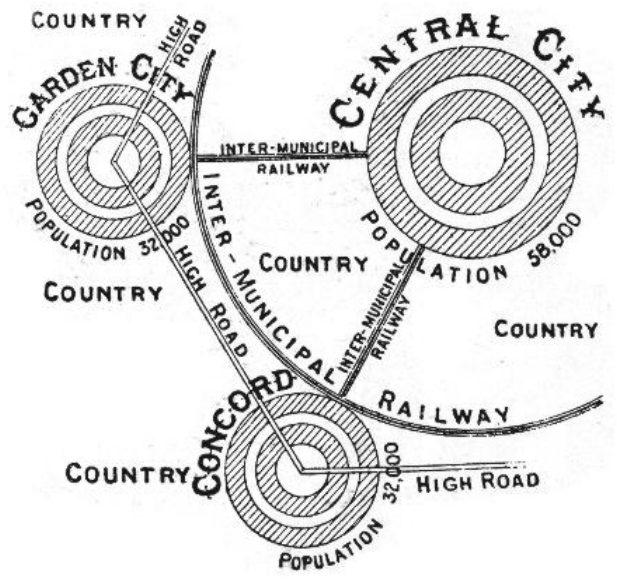

Figure 1. Garden City, 1898

Source: (Osborn \& Mumford, 1946)

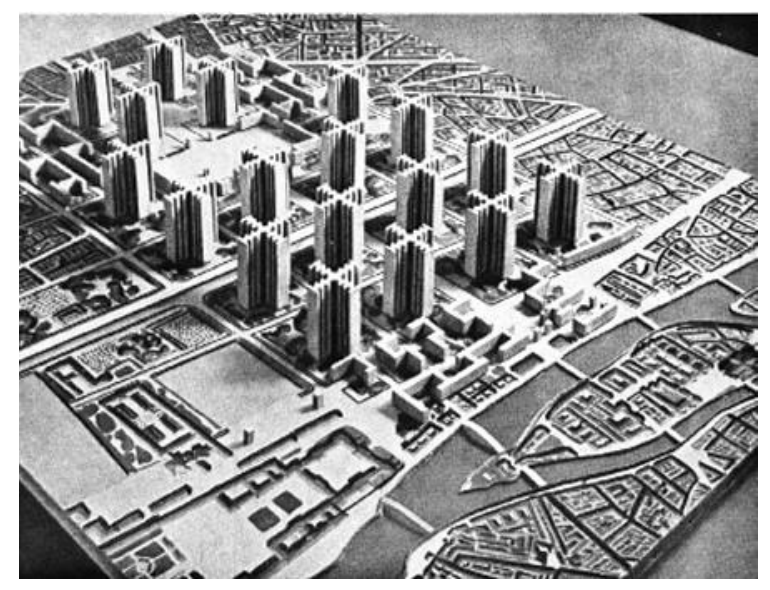

Figure 2. Le Corbusier City, 1933

Source: (Pena, 2010)

The improvement of science and technology after the Industrial Revolution, especially in the field of construction and ability to use new materials in the structure of buildings led towards new movement in architecture and urban design (Akkerman, 2000). This movement was accompanied with two world wars in the beginning of the $20^{\text {th }}$ century, where many cities had been destroyed and needed to rebuild causing raze of many parts of these cities due to the war or the rapid development. Therefore, later the awareness of conservation increased among planners and urban designers, as a reaction of sentimental attachment to old buildings and structures. This point has been reached when many people seem to feel that any new building will be worth less than any old building (Barnett, 1982) The effect of conservation changed the perspective of urban design development, where, people no longer talk about improvement that required clearing the whole districts of a city, but recently urban renewal and redevelopment take the form of a mixture between old and new, for both economic and aesthetic reasons (Barnett, 1982).

Public spaces have formed the background of public life, and supported community's needs for commercial activities, sacred celebrations, social interaction and entertainment (Slessor, 2001).This gave the concept of public space a wide range of notions, from a space of democratic expression, to a space between buildings that fosters human interaction (Varna, 2009). Generally, public space can be seen in various forms, such as streets, squares, plazas, market places and parks (Ercan, 2007). Despite, the role of public space is different between communities, according to each culture and its emphasis on public space. For the Mediterranean cultures, public 
space is presented as squares and open spaces faced town halls and churches, whereas, in Muslim North Africa, public space is limited and usually it is an apart from markets and shopping streets (Slessor, 2001).

While, since the beginning of the $20^{\text {th }}$ century, the movement of modernism influenced the role of public spaces due to its focus on new technologies and materials towards designing functional buildings work as "machines for living in" according to Le Corbusier (Pouliot, 2011). However, this philosophy of modernism has been changed since early 1980s due to the emerging of new spirit of urbanism, with aim to bringing back the characteristics of the traditional city (Ercan, 2007). This situation can be recognized in Britain for example through a number of flagship projects pioneered in order to revitalize and regenerate the derelict lands of industrial estates, declining waterfronts and city centers (Ercan, 2007).

Practically, public spaces are seen as a social binder for residents and a link to the past through showcase personal memories and historical monuments (Carr, Francis, Rivlin, \& Stone, 1992), and helps in creating a sense of community identity and urban well-being (Goodsell , 2003).

Therefore, it can be defined as "the space that is open to all, owned by all and used by all members of the public" (Varna, 2009). Where, the interest of architects, urban designers and planners about public spaces mainly is the result of the following reasons:-

1) Firstly, is to create urban areas with their own identities, and physical design that drives to have an attractive environment (Tibbalds, 1992), to increase the interest in street activities such as street vending, outdoor eating, walking and cycling (Ercan, 2007).

2) Secondly, is to match the demand of service sector, tourists and conventioneers for employees and new markets (Loukaitou-Sideris, 1993), and to provide opportunities for shopping, enjoying, socializing with friends, and meeting with colleagues (Burgers, 2000)

3) Thirdly, the emphasis on city's public spaces is an important strategy to change the city image and put it on the international map as desirable destination. Barcelona for example is one of the most successful re-imaging experiences in Europe which has been expired that through its public spaces (Madanipour, 2005).

4) Fourthly, is to increase the pedestrianization through promoting and implementing the concept of pedestrian malls, as one of the solutions to help the old downtowns to compete with the new suburban shopping centers. (Barnett, 1982).

\subsection{Overview of Historical on Waterfront Development}

As a result of the City Beautiful Movement and the transformation of city's economy from industrial to service during the middle of the $20^{\text {th }}$ century (Carlino \& Saiz, 2008), many of industrial activities and port facilities in cities centers moved to outside and left vast urban lands especially along waterfronts after the decline of old harbor sites (Gospodini, 2001). These lands are suitable urban areas to redevelop and redesign as new public open spaces to reflect a new image of these cities through providing public spaces for recreational and tourism activities (Butuner, 2006). The first attempts of redeveloping waterfronts begun in North America during the 1960s in Baltimore and Boston, then in San Francisco. Where, these projects became later models for the following revitalization projects developed in Europe and North America (Butuner, 2006). In the 1970s this kind of development gradually spread to the other parts of the world (Gospodini, 2001).

In addition, the increasing of competition between cities across the world led for improving the urban image as stated by Short "What sells the city is the image of the city" (Short, 1996). Therefore, many cities decided to reestablish their image of postindustrial city on waterfronts. Sydney and Bilbao are two good examples of promoting their waterfronts, and became worldwide known. Where, around 15 million people visit Sydney's waterfront every year (Butuner, 2006). Eventually, the waterfront development emerged as one of the most important issues of urban design and planning disciplines, because it became an opportunity to improve the social, physical and economical condition of cities (Butuner, 2006). To understand the waterfront evolution practically, a review of waterfront development in Singapore, Istanbul and Malaysia will be showcased.

\subsubsection{Waterfront Development in Singapore}

From the really $19^{\text {th }}$ century, under the British colonial, Singapore emerged as one of the main ports in the southern-east Asia due to its location, for trade and transport. Where, the oldest and most important port of Singapore was located in Singapore River. Later, it became an excellent center of trade, commerce and finance, shaping the heart of Singapore city which initially grew around it. Since the end of the 19th century till the 1970s, most of the shipping businesses in Singapore were done through the river (Goh, 2007), making it a hub of trade and prosperity, where many heavy industrial activities located along the river waterfront (NEA, 2011). These 
heavy activities with time turned the river into an environmental hazard due to high pollution caused by the myriad activities and squatters (Figure 3) (Goh, 2007).

In 1977, Mr. Lee Kuan Yew, who was the Prime minister of Singapore at that time, set the stage for clean-up the river and later develop it to be a focal point of tourism in Singapore. The first stage was to clean the river by remove all sources of pollution and all the rubbish debris from the water (NEA, 2011), by involvement of many government agencies for ten years (Goh, 2007).

The second stage is to provide alternative places for people who were using the river and its banks as place for living or work and trade. Therefore, Housing and Development Board (HDB), Urban Redevelopment Authority (URA) and Ministry of Environment in Singapore from 1977 till 1987, resettled about 26,000 families in flats, over 2,800 industrial enterprises in industrial estates built, and a total of 4,926 street hawkers were shifted to food centers (NEA, 2011).

By 1985, URA set its vision for the future of Singapore River by turn it into a lively activity corridor of the city (Figure 4), according to a Master Plan includes three main strategies (Goh, 2007).

1) Develop an active corridor for recreation and leisure by adopting the concept of mixed land uses including Commercial, Residential, Hotel and Institutional uses. These different activities work to bring people to the area at different times of the day.

2) Mixing old and new developments through keeping the old buildings for the appreciation of future generations, with allowing changing uses of these buildings to increase their viability. Where, new buildings will be constructing in the adjacent areas for commercial and residential purposes.

3) Provide planning framework and guidelines for the private sector to carry out the redevelopment along the river in the future using private resources.

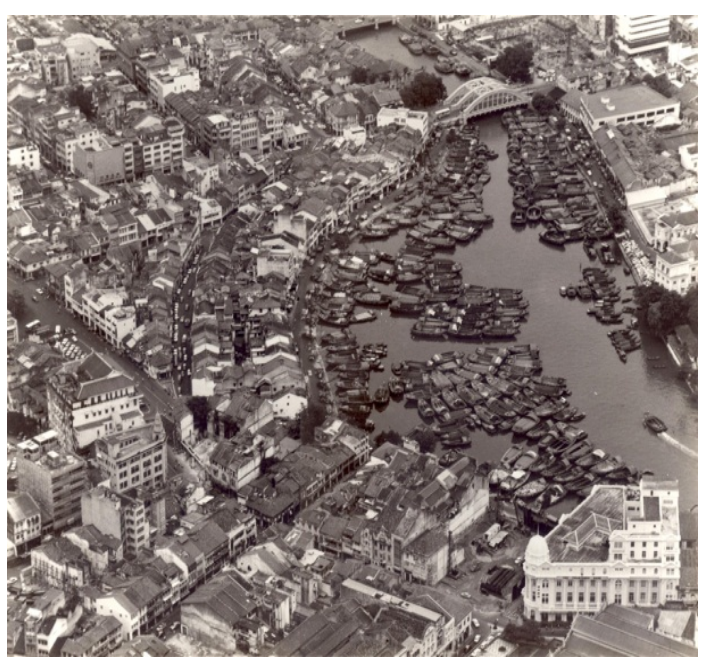

Figure 3. Singapore River before development

Source: (Shang-Wei, 2012)

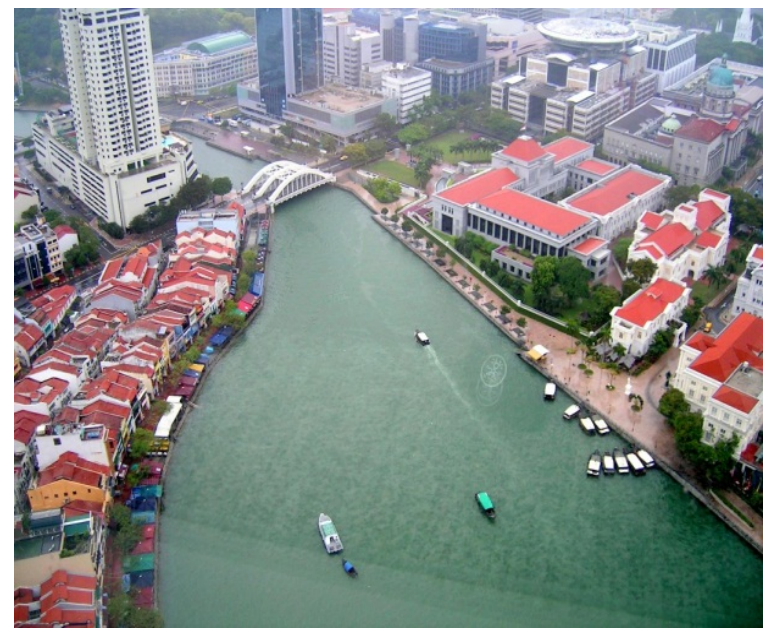

Figure 4. Singapore River after development

Source: (Filmapia, 2006)

\subsubsection{Waterfront Development in Istanbul}

Istanbul is one of the main port cities in the history of Turkey, with high depends on water as a way of trade and transport, place of industrial activities and a recreational area. Hence, in this context, Istanbul has several ports

serving for different purposes acting as important interaction points, and essential elements of urban structure of the city. Almost all ports which are located in the city center, still active and did not experience an abandonment period (Butuner, 2006), and work till now as active points for interaction between Istanbul and outside world. As a result of that, Turkey has a great potential in terms of waterfront revitalization, but in a different way from others. In general, Istanbul is experience waterfront revitalization through two approaches. First one is short-term contains construction of highway and green areas parallel to the water on a land gained by landfills. Second one is long-term and large scale development (Butuner, 2006). Galata Port is a good example of this approach, so it will be discussed here.

Mainly, the significant of Galata comes from that this settlement through the history of Istanbul was the 
economic center of commercial and port activities, with various ethnic and religious groups reflecting a rich social background (Butuner, 2006). So, Turkish Maritime Organization (TMO) was introduced the project of Galata port by 1998 to be one of the projects that will change the image of Istanbul (Erbas, 2007), and to replace Karakoy port which had become unsuitable for the increasing traffic of vessels and trucks (Butuner, 2006).

TMO decided to build Galata Port as a passenger port covering a land of $100.000 \mathrm{~m}^{2}$ in an important historical quarter of the city, similar to models that were developed in western countries (Butuner, 2006). The project contains cruise port, five star hotels, shopping malls, restaurants, cafés, entertainments places, cinema and theatre halls, underground car parks for the private cars and buses (Erbas, 2007). All this is to create an international culture and tourism center, and to develop Istanbul's image in the national and international level (Butuner, 2006), see (Figures $5 \& 6$ ).

On the other hand, an urban project with this scale naturally will be under the discussion and criticism of different groups of NGOs, media and local people. This rose from the confidentiality of the area, where the project will be constructed, causing a losing and destroying of the historical characteristics (Butuner, 2006). Secondly, the project is developed for a limited area making barrier between the city and the sea (Erbas, 2007). Thirdly, it is preventing the public access to the waterfront (Butuner, 2006), and closing the view connection between the water and the city since the front side of it will be surrounded by high buildings (Erbas, 2007).

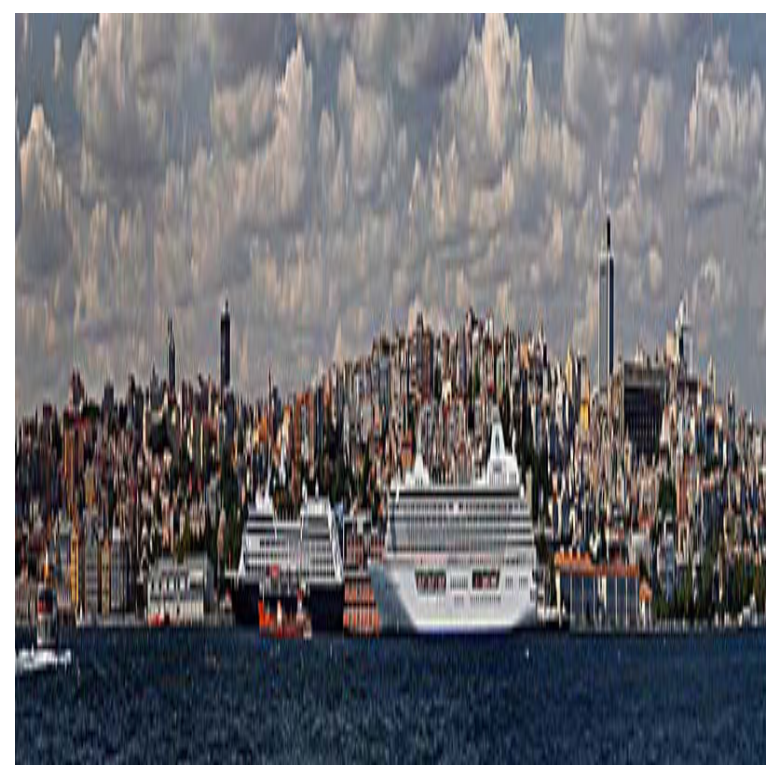

Figure 5. Galata Port in Istanbul

Source: (Butuner, 2006)

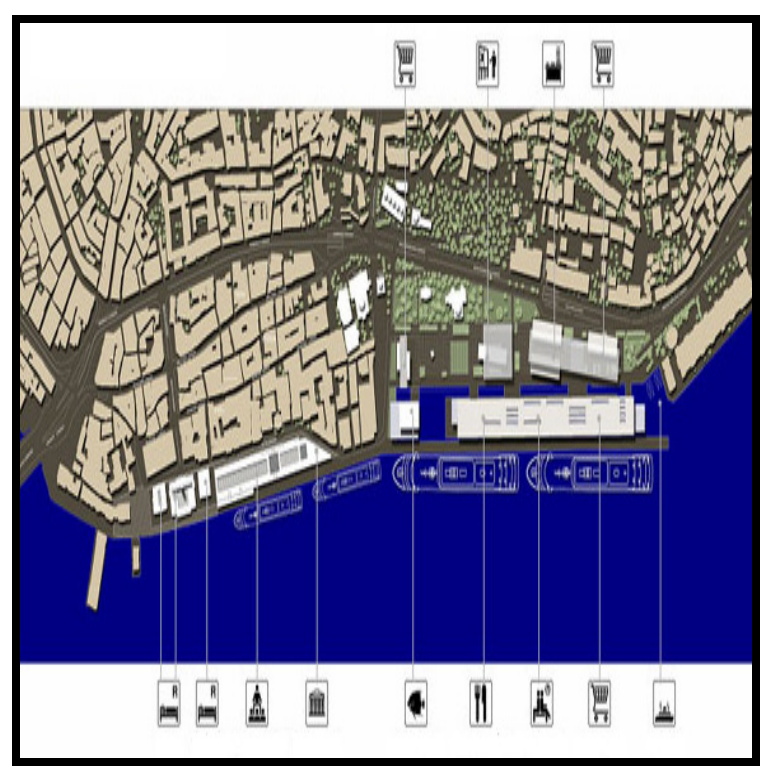

Figure 6. Site Plan of Galata Port in Istanbul

Source: (Erbas, 2007)

\subsubsection{Waterfront Development in Malaysia}

Malaysia can call itself a water rich nation with a big number of rivers and coastal areas, giving a great potential for trade and transport (Hussein, 2006). Hence, many urban cities in Malaysia such as, Kuala Lumpur, Terengganu, Malacca, and Johor Bharu are grown up along rivers or coastal areas (Andaya \& Andaya, 2001).

Waterfront development of Malaysia is focused more on public purposes and mixed used development contains housing and commercial projects. Whereas, historically, waterfront in Malaysia has several changes over decades which can be divided into 4 periods as below (Yassin, Eves, \& McDonagh, 2010): -

1) Colonial rule (1887 - 1956): - During this period, water was the most important domestic way for trade and transport. Therefore, waterfront of several port towns had been grown dramatically for business activities.

2) After independence and early urbanization (1957-1969): - development continued along the river edge with establishment of the perception "rivers as public open space corridors". However, due to the governmental program of $\mathrm{FELDA}^{(*)}$, many of rivers' population moved to urban areas under the relocation scheme programs.

3) Urban explosion of industrialization period (1970-1997): - Urban explosion caused a reconstruction of cities and rural areas side by side with upgrading transportation system and moving of industrial activities under the 
NEP (New Economic Policy) $)^{(* *)}$. As a result of that, waterfront's functions declined and the riverfronts remained with pollution and traditional settlement.

(*) FELDA: Federal Land Development Authority is a Malaysian government agency handling the resettlement of rural poor into newly developed areas established on July 6, 1956.

$(* *)$ NEP: New Economic Policy was an ambitious and controversial socio-economic restructuring affirmative action program, launched by the Malaysian government in 1971 and ended in 1990

4) Technology, Modernization and Vision 2020 (2000 - present): - Since the end of the 1990s, the urban population increased in Malaysia to reach 62 percent due to the increasing of job opportunities and facilities provided in cities. Therefore, this urban sprawl and city reshaping drove the government to emphasize on waterfront for two main reasons, redevelopment and revitalization.

In this context, Kuching waterfront development which propose in 1989 and started in 1993 can be considered as the benchmark of waterfront development in Malaysia, which becomes a new trend of development all over the country and popular amongst the developers (Yassin, Eves, \& McDonagh, 2010). Nowadays, many waterfronts have been developed in several states of Malaysia, such as the development of Johor Bharu waterfront, which will be discussed as a case study.

\section{Methodology}

A literature review presented to showcase the development of theoretical and conceptual framework of urban design with focusing on public space as a main component. The review focused on waterfront development of Singapore and Turkey as a world cases and the local experience of Malaysian waterfront development in Johor Bahru. In addition, the study highlighted the main factors that affect the application of the theoretical ideas on the ground in terms of waterfront development as a type of public spaces within the urban design framework.

\section{Findings}

\subsection{Johor Waterfront Development as a Case Study}

The importance of this project comes from that Johor is considered as the third significant state in Malaysia due to its strategic location in the southern portion of peninsular Malaysia (close to Singapore and Indonesia), with high population over than 3.3 million (Department of Statistics, 2011), and high standard of development. Johor Bahru, the capital city of the state, is a rapidly growing city with urbanization rate of $69.1 \%$ (National Physical Plan, 2005), has heritage iconic buildings, skyscrapers clustered within the city center, and low scale development dominated by traditional shop houses. Physically, the city is defined by streets that contain commercial and government activities leads to Johor Bahru waterfront (Comprehensive Development Plan, 2006).

Therefore, the variety of activities, buildings and places drive about $60 \%$ of foreign tourists who visit Malaysia to Johor Bahru and give the city a strong prospect to be Malaysia's second largest city (IRDA, 2008). Due to that, the comprehensive development plan of South Johor Economic Region (SJER) established to guide the future economic, social, environmental and physical development in the south part of Johor (Ramli \& Akmal, 2006). The first goal of this plan is to create livable community, well designed and well connected through protect and conserve natural, historic and open space resources to improve the quality of life (Ramli \& Akmal, 2006). For that, the plan aims to develop a distinctive Central Business District (CBD) as a preservation area through encouraging diversity of land use, and mixing between heritage and modern buildings (IRDA, 2008).

The new CBD will include three main precincts (Johor Bahru City Waterfront Precinct, Heritage Precinct, Business and Central Park Precinct), to regenerate the older and uneconomical land into prime properties through creating new public spaces and public amenities to meet the needs of increasing young population, and to enhance the built environment of the city by providing the 'breathing' space which the city needs (Comprehensive Development Plan, 2006).

In addition, the plan also aims to enhance the waterfront area of Johor Bahru that faces Singapore as an excellent opportunity to reshape the coastal area with vibrant. SJER is a plan that covered the logistic triangle from Senai Airport to the north, Port of Tanjung Pelepas (South West) and Johor Port in Pasir Gudang (South East), encompassing an area of 2,217 sq km, aims to provide a facilitative environment for investors and consumers (Khazanah Nasional, 2006). The waterfront will link Johor Bahru City Centre to Danga Bay (Comprehensive Development Plan, 2006). This development will create an attractive feature for the city and provide unique components by emphasis on public spaces and plazas for shaping a new image through linking between conservation and heritage precinct with the waterfront areas (Comprehensive Development Plan, 2006). 
On 38.23 acres of reclamation land, the new waterfront will be created as a new focal point with potential to be developed for public use as recreational and low-rise commercial project (Ramli \& Akmal, 2006). According to the Comprehensive Development Plan of Johor Bahru, waterfront will be guided through the following strategies:

1) Overcome the barrier of Selat Tebrau Highway, to ensure a good connection between CBD and the waterfront, through extend the streets and commercial activities of the city center to the waterfront (Figure 7).

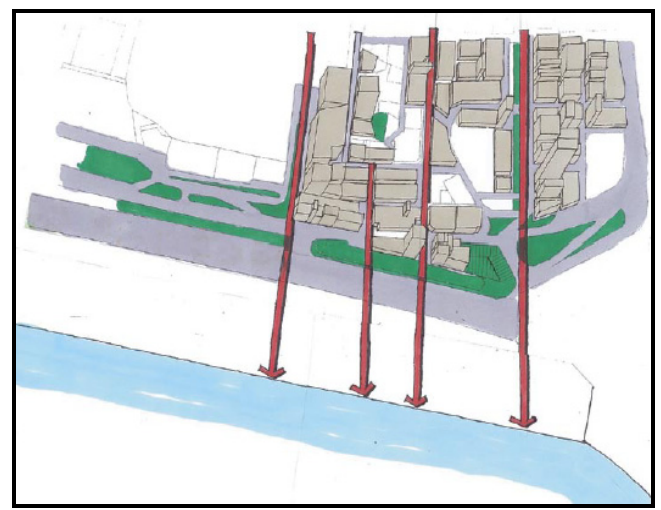

Figure 7. Extend the streets of CBD to the waterfront

Source: (Comprehensive Development Plan, 2006)

2) Create a network of pedestrian linkage in form of pedestrian overhead bridges and underpass to link the whole CBD with the waterfront area and to have good connections with more accessible for pedestrians (Figure 8).

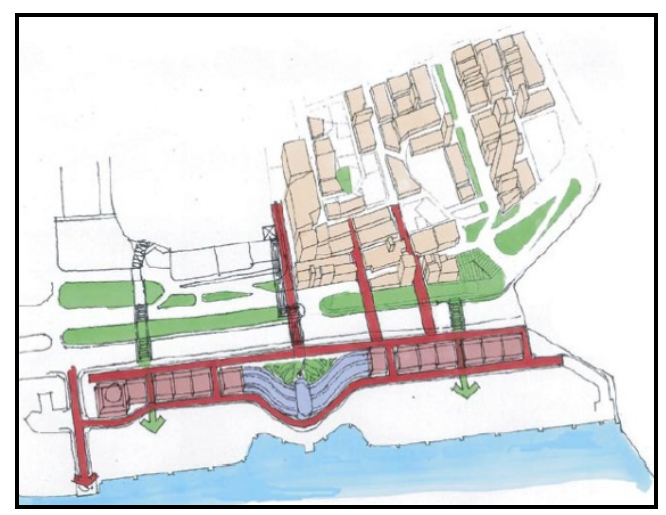

Figure 8. Pedestrian linkages between CBD and waterfront

Source: (Comprehensive Development Plan, 2006)

3) Low-rise commercial development with three storey or not more than 12 meters height, to ensure that certain landmarks of the city will not visually affected by the new development of waterfront, and to provide visual corridors linked to the city center (Figure 9) 


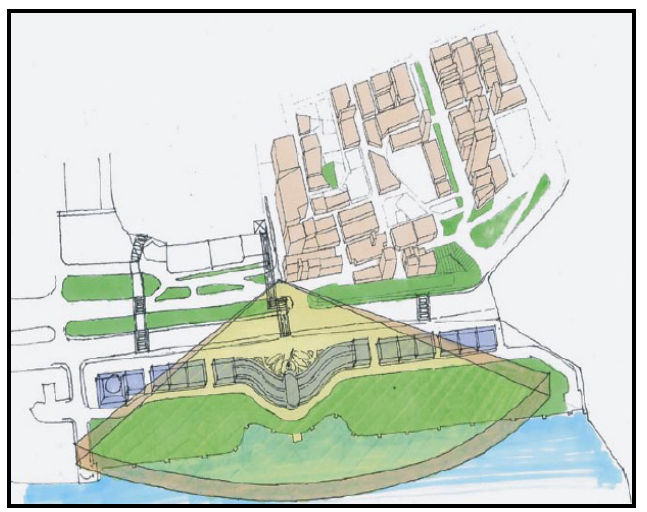

Figure 9. Visual analysis towards waterfront development

Source: (Comprehensive Development Plan, 2006)

4) Instillation of vibrant cultural environment including arts, entertainment, and other cultural activities, to promote tourism, international prestige, which leads to enhance the city's image and rejuvenate the waterfront areas (Ramli \& Akmal, 2006) (Figure 10).

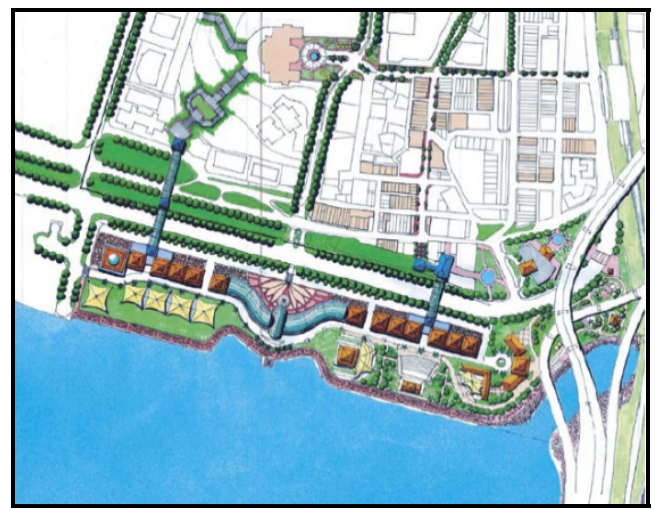

Figure 10. The concept master plan

Source: (Comprehensive Development Plan, 2006)

\section{Discussion and Recommendations}

As a result of this review, it can be seen essentially that urban design concept is evolving towards mix land development as a strategy to provide social and economic interaction and integration. This development is framed by conservation to protect the distinctive identity and image of urban fabric and to be able for competition with other cities.

In the core of this strategy, public space works as a stimulated environment for interaction, due to its ability to contain different activities, different people and different cultures in the same time within the same place.

Therefore, Malaysia has a good ability to develop a unique public space environment based on its rich diversity of cultures, ethnics and history. These public spaces can be the vessel of interface among local people, and between local with tourists for exchanging ideas and cultures. This will increase the familiarity and linkages between the city and its people whether they are local or tourists. Waterfront as a type of public spaces should have the same aspects, which means, it has to be the space that is open, owned and used by all members of the public. Through providing accessibility and activities can match the needs for wide range of people. However, sometimes it turns into private space as in Istanbul case, because it has been developed separately from the city context with design follows the western examples, rather than adopts or respects the heritage architecture of Istanbul, in addition to limitation of access and activities, which are provided for tourists.

The importance of waterfront is not only as a public space for recreation and entertainment but as an open gate for social and economic exchange between the city and outside world, which Istanbul missed in Galata 
waterfront due to above reasons. On the other hand, waterfront had been for long time the most active place within the city structure till it faced the situation of abandonment. Mainly as a result of pollution, shifting of industrial activities, changing of transportation ways and methods, relocating of ports and increasing of slam areas around water banks. These reasons are the rest of very flash period of success.

The abandonment of waterfronts led to change them from places for trade, transport and industry to be places for recreation and entertainment towards opening a new page of waterfronts' success. However, the question which has to be picked up is about which factors may be able to affect this new success. Generally, the limitation of access and activities, ability to reflect the city in terms of identity, culture and image, attractiveness for local and tourists and eventually environmental issues such as pollution which are one of the main reasons for success or decline of any waterfront project.

Moreover, adopt a well design progress for waterfront development is important factor to achieve project's success. The development process should include 3 stages as in Singapore case. Firstly, provide plan to relocate existed people or activities that are already on the waterfront area. Secondly, solve all the issues and problems that may affect the development of the waterfront such as pollution, access and so on. Thirdly, plan and develop towards achieve the vision of the project.

Malaysia with its long coastal area, rich environment and variety of ethnics and cultures, represents a great opportunity for waterfront development as a strategy to enhance foreign investment for commercial and recreational projects. These investments will let Malaysia to increase its ability to attract more tourists, and provide new job opportunities for local people. Nevertheless, the development has to respect environmental issues and local architecture and culture, to be able to reflect the image of Malaysia in a sustainable way, and to compete with other countries.

In particular, Johor with its location close to (Singapore and Indonesia) can be considered as the southern national gate of Malaysia, through develop several waterfront projects for different purposes, where, Johor Bahru waterfront is one of them.

The main concept of Johor Bahru waterfront is to conserve and maintain the heritage CBD of the city as a background for the waterfront, by connecting them through roads and pedestrian ways, and guide buildings' heights of the waterfront so it will not cover the CBD's buildings. This concept drives us to conclude that waterfront is not only the area that faces a water body but it is any area, building or public space that has a physical or virtual linkage to a water body.

\section{Conclusion}

The significant value of waterfront makes it imperatives for us to be very careful in design, develop and manage waterfront projects, because, it is shaping and reflecting the image of the city and providing a linkage to the outside world for social and economic interaction. Therefore, as an assumption for this review of waterfronts' development, several main strategies can be listed to assist in develop and design waterfronts in Malaysia with conservation of heritage urban fabrics to develop the abandonment waterfront and improve the social, economic and physical conditions of the old parts of cities. Mixed land development between heritage and new buildings, and between different activities including recreation, commercial, housing and so on, to provide space and activities for all kinds of people in different times for economic and aesthetic purposes. In other hand, reflection of culture, identity and characteristics of the society on waterfront to upgrade the city image as an attractive link to outside world and promote cities for international tourism. The local government should be more emphasized on implement sustainable development in waterfront projects to protect the environment and reduce causes of pollution as well as develop waterfront as a part of the city by link it to the CBD and other important parts of the city.

\section{References}

Akkerman, A. (2000). Harmonies of Urban Design and Discords of City-form: Urban Aesthetics in the Rise of Western Civilization. Journal of Urban Design, V, 267-290. http://dx.doi.org/10.1080/713683970

Andaya, B. W., \& Andaya, L. Y. (2001). A history of Malaysia (2nd ed.). London: Palgrave Macmillan.

Barnett, J. (1982). In C. Linda Dingler (Ed.), An Introduction of Urban Design. New York: Fitzhenry \& Whiteside Limited.

Buck-Morss, S. (1990). The Dialectics of Seeing: Walter Benjamin and the Arcades Project. Cambridge: MIT Press. 
Burgers, J. (2000). Urban landscapes: On public space in the postindustrial City. Journal of Housing and the Built Environment, (15), 145-164. http://dx.doi.org/10.1023/A:1010120012629

Butuner, B. (2006). Waterfront Revitalization as a Challenging Urban Issue in Istanbul.

Carlino, G. A., \& Saiz, A. (2008). City Beautiful. IZA.

Carr, S., Francis, M., Rivlin, L., \& Stone, A. (1992). Public Space. Cambridge: Cambridge University Press.

Comprehensive Development Plan. (2006). Comprehensived development Plan for South Johor Economic Region 2006-2025. Kuala Lumpur: Khazanah Nasional Berhad.

Department of Statistics, Malaysia. (2011). Population and Housing Census, Malaysia 2010 (2010 Census). Retrieved July 30, 2012, from http://www.statistics.gov.my/portal/index.php?option=com_content\&view=section\&id=21\&Itemid=154\&la $\mathrm{ng}=\mathrm{en}$

Erbas, A. (2007). Port Regeneration and Sustainable Urban Development, The Case of Galata Port and Haydarpasa Port Projects in Istanbul After 2000. 43rd ISoCaRP Congress.

Ercan, Z. M. (2007). Public spaces of post-industrial cities and thier changing roles. METU JFA, 15-137.

Filmapia. (2006). Singapore River. Retrieved August 15, 2012, from http://www.filmapia.com/published/places/singapore-river

Goh, M. (2007). Singapore's Waterfront Rejuvenatoin Efforts. Singapore delivered to the Harbour Business Forum Luncheon. Hong Kong.

Goodsell, C. T. (2003). The Concept of public Space and its democratic Manifestations. SAGE, 361-383.

Gospodini, A. (2001). Urban Waterfront Redevelopment in Greek Cities, a Framework for Redesigning Space. Elsevier Science Ltd, 18(5), 285-295.

Hussein, H. (2006). Urban recreational riverfronts: Successful revitalisation elements. Journal of Design and the Built Environment, I(2).

IRDA, I. R. (2008). Important facts and details on Johor Bahru City Centre. Johor: Iskandar Regional Development Authority.

Loukaitou-Sideris. (1993). Privatisation of public open space: Los Angeles experience. Town Planning Review, 139-167.

Madanipour, A. (2005). Public spaces of European cities. Nordisk Arkitekturforskning.

Moughtin, C. (1992). Urban Design: Street and Square. Boston: International books.

Nasional, K. (2006). Khazanah Nasional Berhad ("Khazanah") and the proposed South Johor Economic Region ("SJER"). Kuala Lumpur: Khazanah Nasional.

National Physical Plan. (2005). National Physical Plan. Ministry of Housing and Local Government.

NEA. (2011, January ). Singapore River Clean Up: Against the Odds. Envision, (1), 14-17.

Osborn, F. J., \& Mumford, L. (1946). Garden Cities of to-morrow. Retrieved June, 2012, from http://www.library.cornell.edu/Reps/DOCS/howard.htm

Pena, J. (2010, December). Gaia Critiques Paternalistic Urbanism. Retrieved June, 2012, from http://www.curbsandstoops.com/gaia/

Pouliot, H. (2011). Machines for living reflections on Le Corbusiers Plan Obus (Algiers) \& Unité de Habitation (Marseilles). Graduate Journal of Visual and Material Culture, (4).

Ramli, A. R., \& Akmal, A. (2006). South Johor Economic Region (SJER) Comprehensive Development Plan. Tokyo Academic, Industry \& Cultural Integration Tour. Tokyo: Shibaura Institute of Technology.

Roberts, M., \& Greed, C. (2001). Approaching Urban Design. Edinburgh Gate, Harlow, UK: Longman.

Shang-Wei, K. (2012). Kouo Shang-Wei. Retrieved June, 2012, from http://donors.nl.sg/A13_2.asp

Short, J. R. (1996). The Urban Order: An Introduction to Cities, Culture and Power. Blackwell Publishers.

Slessor, C. (2001). Public Engagement - evolution of public space.'

Tibbalds, F. (1992). Making People-friendly Towns. Essex: Longman. http://dx.doi.org/10.4324/9780203469521

United Nations. (2010). World Urbanization Prospects, the 2009 Revision. New York: United Nations. 
Varna, G. (2009). Designing the sustainable city: the role of public space. Universitas 21 International Graduate Research Conference (pp. 187-194). Melbourne \& Brisbane: Department of Urban Studies, University of Glasgow.

Yassin, A. B., Eves, C., \& McDonagh. (2010). An Evolution of Waterfront Development in Malaysia: From History to Modernization.

\section{Copyrights}

Copyright for this article is retained by the author(s), with first publication rights granted to the journal.

This is an open-access article distributed under the terms and conditions of the Creative Commons Attribution license (http://creativecommons.org/licenses/by/3.0/). 